\title{
THE EFFECT OF DIFFERENT AMERICAN VINE ROOTSTOCKS ON THE PHYTOCHEMICAL CHARACTERISTICS IN DRIED BANAZI BLACK GRAPE (VITIS VINIFERA L.)
}

\author{
ÇAKIR, A. ${ }^{1 *}-$ ŞAHINER ÖYLEK, $\mathrm{H}^{2}$ \\ ${ }^{1}$ Department of Horticulture, Faculty of Agriculture, Bingol University \\ 12000 Bingol, Turkey \\ ${ }^{2}$ Apricot Research Institute \\ Malatya, Turkey \\ (e-mail: haticesahiner@hotmail.com) \\ *Corresponding author \\ e-mail: acakir@bingol.edu.tr, cakiratilla@gmail.com \\ (Received $6^{\text {th }}$ Jul 2017; accepted $2^{\text {nd }}$ Oct 2017)
}

\begin{abstract}
Banazi Black grape which is almost never consumed freshly is a very important, seed bearing, local type which is directly dried in the sun with its cluster without any processing. Ungrafted (5 years old and over 40 years old) and grafted (41B, 99R, 1103P and 110R) Banazi Black grape varieties which were 5 years old were used in the study conducted in Turkey, Malatya, Yesilyurt district, Konak town. The grapevines in the farmer vineyards, grown in dry conditions, were established in the form of blocks, serpene cultivation was applied on the stocks, and cane training was made. The photochemical characteristics of the dried grape belonging to the rootstocks used in 5 year-old Banazi Black grape which were ungrafted (5 and 40 years old ungrafted) and grafted with 41B, 99R, 1103P, 110R rootstocks were investigated in this study. It was determined from the analyzed phenolic compounds that gallic acid was $4.10-14.43 \mathrm{mg} / \mathrm{kg}$; catechin was 146.87 $306.87 \mathrm{mg} / \mathrm{kg}$, rutin was $38.96-78.15 \mathrm{mg} / \mathrm{kg}$, naringin was $22.54-50.97 \mathrm{mg} / \mathrm{kg}$, phloridzin was 40.03 $107.72 \mathrm{mg} / \mathrm{kg}$, and quercetin was $0.47-1.67 \mathrm{mg} / \mathrm{kg}$. Total antioxidant capacity in total phenolic substance rootstocks was determined to be $0.19-0.22 \mathrm{mg}$ trolox equivalent/g; gallic acid/g was 7.51$21.66 \mathrm{mg}$. The amount of resveratrol was between $0.19-1.30 \mathrm{mg} / \mathrm{kg}$ among the rootstocks. The differences between the rootstocks were statistically significant in terms of phenolic compounds. 40 year-old ungrafted vinestock took a higher value when compared to the other rootstocks in terms of phenolic compounds.
\end{abstract}

Keywords: dried grape, grafted-ungrafted, antioxidant content, phenolic content, Malatya

\section{Introduction}

Turkey is an important vine cultivation center in the world. According to the data of TÜİK [Turkish Statistical Institute] (2016), 4,000,000 tones grapes, including 1,990,604 tones table, 1,536,269 tones dried, and 472,534 tones wine grapes, were grown totally in the 4,352,269 da. area in Turkey (Anonymous, 2017).

The farming of cultivated grapevine (Vitis vinifera L.) has been conducted in Turkey since 6000-5000 B.C. (Doğer, 2004). Grapevine is an important cultivated plant in Turkey as it is economical in terms of grape yield and a genetic material with its abundant varieties. (Celik, 1998; Celik et al., 1998). This abundance of the grapevine gene potential creates an important source for both the rehabilitation works and the production of the local types that have economic importance.

Grapevine has always kept its value among the agricultural products with its richness in terms of gene potential, its economic importance, and its significance in human nutrition and health. Generally, there are water, sugars, organic acids, phenol 
compounds, pectic substances, aroma substances, nitrogenous substances, enzymes, vitamins and minerals in the compound of grapes (Fidan and Yavas, 1986; Canbas, 2003; Jackson, 2003).

The species and varieties of grapevines are the foremost plant species that are rich in phenolic compounds (Lohachoompol et al., 2004). These compounds are synthesized structurally in all organs of the grapevine and their proportions in fruit and seeds are affected by environmental conditions (Ough and Amerine, 1988).

Phenolic components which are defined as the secondary metabolism products of the plants are the primary natural compounds standing out with their antioxidant characteristics in terms of human health. According to scientific studies, phenolic compounds have antiallergic, antiinflammatory, antidiabetic, antimicrobial, antipathogenic, antiviral and antithrombotic effect (Knekt et al.,1996; Le Marchand et al., 2000; MacDougall, 2002; Aras, 2006; Kafkas et al., 2006).

One of the distinguishing characters of the colorful (red, black) grapes is phenolic compounds. It has been determined in the researches that colorful types are richer than white types in terms of phenolic substances (Cemeroğlu, 2004).

Just as each grape variety has a different tendency in terms of soil and climate, their response to the American grape-vine rootstock on which they are grafted may be different. For this reason, the most appropriate chemical component a grape type can reach is directly related to the soil structure and climate of the territory it is cultivated in and the rootstock on which it is grafted (Amerine et al., 1972; Jackson, 2000; RibéreauGayon, et al., 2000; Canbas, 2006; Kelebek, 2009; Rolle et al., 2010).

There are some studies on the influence of the local grape varieties in Turkey, the vineyards that they are cultivated in, and the climatic conditions on the phenolic compounds of the grapes, yet these studies are not enough. However, vine cultivation activities are distributed in different geographical regions in our country which have different climatic characteristics. The fact that these regions have different characteristics in terms of climatic and soil conditions will make a difference in terms of phenolic compounds which directly affect the quality factor of our local grape varieties. For this reason, new studies which will deal with our local grape varieties the regions in which they are cultivated are needed.

Banazi Black grape is cultivated throughout Malatya, but it has specifically adapted to Konak town (Banazi), Yesilyurt and Akcadağ districts which are located in 1000$1300 \mathrm{~m}$ above sea-level (Koc et al., 2015).

People prefer ungrafted cultivation, since they think grapes have a specific taste, flavor, and color. However, the fact that the vineyards in the region are limy and waterless led people to use rootstocks resistant to lime and aridness. The use of rootstocks is important because it provides earliness in Banazi Black grape (Koc et al., 2015).

It was determined in the studies that phenolic compound concentration varies by grape variety, the environment it is cultivated and environmental factors. This study aims to determine some photochemical characteristics of Banazi Black grape, which has adapted to Malatya Yesilyurt ecology and is cultivated with or without grafting, within the scope of the significance of rootstock-variety relationship in vine cultivation. 


\section{Materials and methods}

\section{Material}

Our study, the analyses of which were carried out in Malatya Apricot Research Institute research and application laboratories, was conducted in $2014\left(38^{\circ} 16^{\prime} 53.31^{\prime \prime} \mathrm{N}\right.$ - 38 $17^{\prime} 13.38^{\prime \prime} \mathrm{E}$, at $1290 \mathrm{~m}$ altitude) (Figure 1).

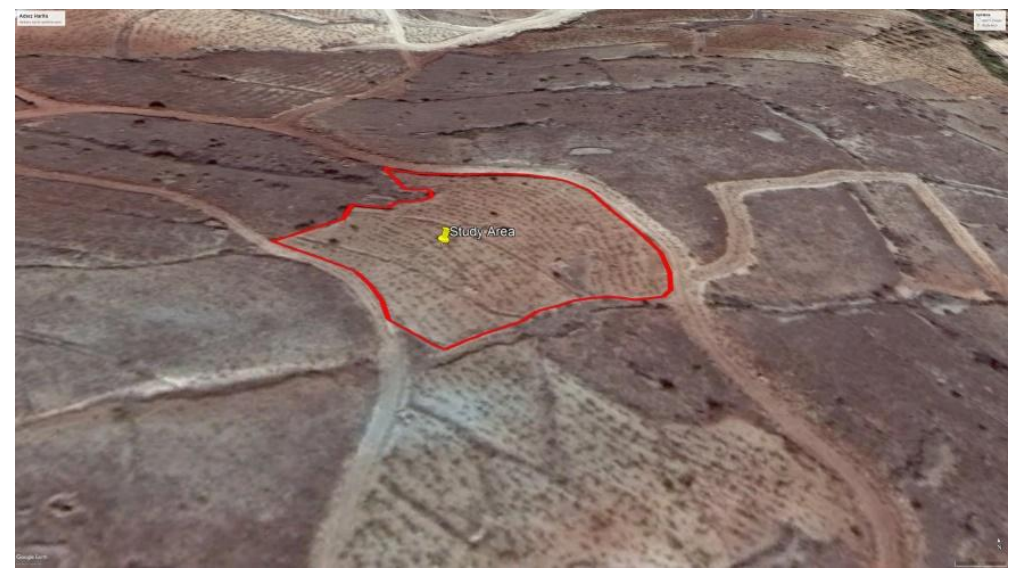

Figure 1. The research center where the experiments were conducted

The materials of the study are ungrafted 5 and 40-year old Banazi Black grape and 5 year-old Banazi Black grape variety grafted on 41B, 99R, 1103P, 110R American grape-vine rootstocks.

The study was conducted in the farmer vineyard, where serpene cultivation was applied on the stocks shaped like blocks in dry conditions with $2 \times 2$ distances and cane training was made, in the control of Malatya Apricot Research Institute personnel in Malatya Konak (Upper Banazi) area which is $1290 \mathrm{~m}$ above sea-level.

Banazi Black grape which ripens between September $10^{\text {th }}$ and $20^{\text {th }}$ is a seed bearing, local variety which is dried in clusters and put on market naturally. Grapes are blueblack, globular and moderate-sized. The fact that it is dried with its cluster provides a perceptual superiority for the consumer. The clusters are conical, medium (250 g-350 g) and dense (Figure 2).

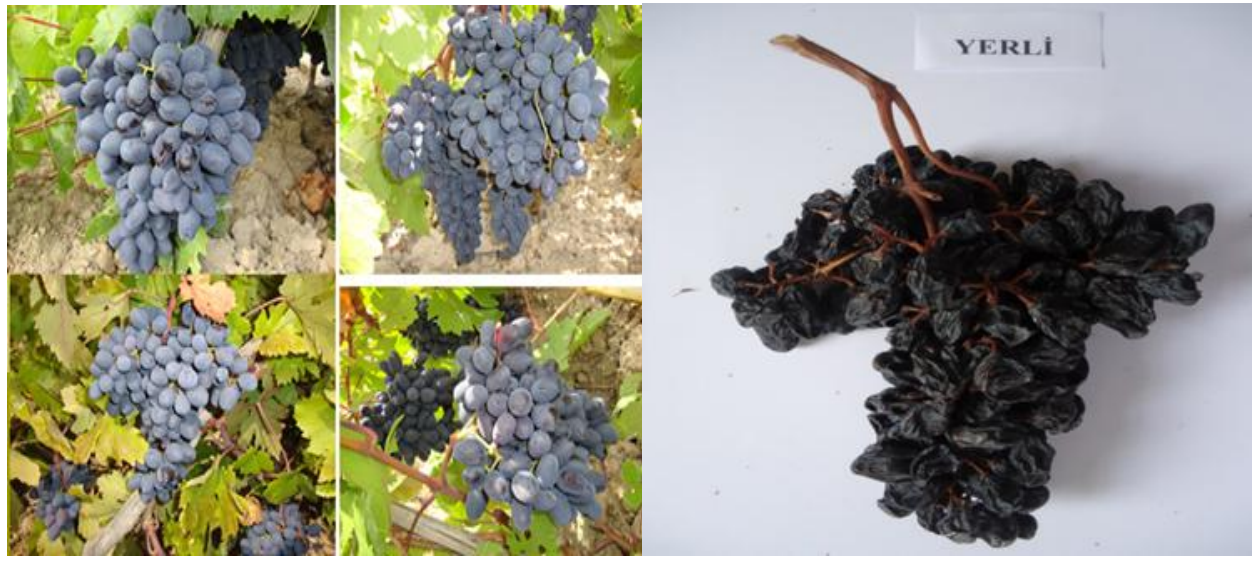

Figure 2. Fresh and dried Banazi Black grape fruit 
It is not subjected to any chemical process during drying process. Harvest starts when the first withering appears on the grapes of the cluster on the stock. The clusters that are harvested are subjected to drying process either directly on the soil or on the cloths laid on the soil (Figure 1) Drying process lasts between 5-9 days (Koc et al., 2015).

\section{Geographic position of the research location}

Yesilyurt, which is one of the two central districts of Malatya with its surface area of $1013 \mathrm{~km}^{2}$, is surrounded by Battalgazi on the east, Akcadağ and Doğansehir on the west, Celikhan and Adiyaman on the south, Yazıhan on the north. Yesilyurt district where the vineyard used in the test is located is on a transit area between Southeastern Anatolia Region terrestrial precipitation and Mediterranean Region marine precipitation, and between Eastern Anatolia Region terrestrial precipitation and Central Anatolia Region precipitation (Anonymous, 2015).

\section{Soil characteristics of the research location}

Earth sample taken from 0-30 cm depth in the vineyard was analyzed in Malatya Apricot Research Analysis Laboratory (Table 1).

Table 1. Soil analysis values of the test field

\begin{tabular}{c|c|c|c|c|c|c|c}
\hline $\begin{array}{c}\text { Saturation } \\
(\boldsymbol{\%})\end{array}$ & $\mathbf{p H}$ & $\begin{array}{c}\text { Total salt } \\
(\boldsymbol{\%})\end{array}$ & $\begin{array}{c}\text { Lime } \\
(\boldsymbol{\%})\end{array}$ & $\begin{array}{c}\text { Organic matter } \\
(\boldsymbol{\%})\end{array}$ & $\begin{array}{c}\mathbf{E C} \\
(\boldsymbol{\mu} \mathbf{S} / \mathbf{c m})\end{array}$ & $\begin{array}{c}\mathbf{P} \\
(\mathbf{k g} / \mathbf{d a})\end{array}$ & $\begin{array}{c}\mathbf{K} \\
(\mathbf{k g} / \mathbf{d a})\end{array}$ \\
\hline 51.70 & 7.75 & 0.0228 & 37.90 & 1.33 & 0.69 & 8.48 & 77.89 \\
\hline
\end{tabular}

It can be seen on Table 1 that since saturation value is 51.70, vineyard where the research was conducted has "Clay-Loam" soil. It can be seen that the test field is saltless with a value of $0.02 \%$, is very limy with $37.90 \%$ lime ratio, has low organic substance with $1.33 \%$ ratio, and has an adequate structure with $8.48 \mathrm{kd} / \mathrm{da}$ phosphor and $77.89 \mathrm{~kg} / \mathrm{da}$ potassium. It was determined that it had loose-alkali structure with $7.75 \mathrm{pH}$ and its electrical conductivity EC $(\mathrm{mS} / \mathrm{cm})$ value was 0.690 . As a consequence of the soil analysis 300-400 g sulfur and 15-20 kg burnt farm manure were applied on each stock during the early spring.

\section{Climatic characteristics of the research location}

Some important meteorological data belonging to Malatya-Yesilyurt district ecology where the research was conducted are given on Table 2 and Table 3 (Anonymous, 2015).

The ripening of the clusters belonging to the stocks coincided with September in which the average temperature was $22.7^{\circ} \mathrm{C}$ during the time when the research was conducted in 2014. During the harvest season in this year total precipitation was $53.8 \mathrm{~mm}$ for September, monthly average relative humidity was $32.6 \%$, and minimum temperature was $8.3{ }^{\circ} \mathrm{C}$ for September, 2014 (Table 3). 
Table 2. Some climatic data belonging to the research location

\begin{tabular}{c|c|c|c|c|c|c|c|c}
\hline \multirow{2}{*}{ Months } & \multicolumn{3}{|c|}{$\begin{array}{c}\text { Monthly minimum temperature } \\
\left({ }^{\circ} \mathbf{C}\right)\end{array}$} & \multicolumn{4}{c}{$\begin{array}{c}\text { Monthly average temperature } \\
\left({ }^{\circ} \mathbf{C}\right)\end{array}$} \\
\cline { 2 - 9 } & $\mathbf{2 0 1 1}$ & $\mathbf{2 0 1 2}$ & $\mathbf{2 0 1 3}$ & $\mathbf{2 0 1 4}$ & $\mathbf{2 0 1 1}$ & $\mathbf{2 0 1 2}$ & $\mathbf{2 0 1 3}$ & $\mathbf{2 0 1 4}$ \\
\hline January & -5.2 & -10.0 & -9.6 & -4.3 & 2.4 & 0.6 & 0.9 & 4.1 \\
February & -6.1 & -10.0 & -4.5 & -7.2 & 3.1 & -1.5 & - & - \\
March & -1.7 & -6.5 & -3.9 & -3.4 & 8.4 & 3.4 & 8.8 & 10.4 \\
April & -0.9 & 3.6 & 5.7 & 1.4 & 12.2 & 14.9 & 14.9 & 15.4 \\
May & 6.6 & - & 9.5 & 9.9 & 17.0 & - & 19.5 & 19.6 \\
June & 12.9 & 11.0 & 12.6 & 12.4 & 23.5 & 25.6 & 24.5 & 23.9 \\
July & 16.6 & 13.9 & 16.1 & 19.0 & 29.0 & 28.7 & 27.2 & 30.3 \\
August & 15.1 & 16.4 & - & 18.8 & 28.0 & 28.3 & - & 30.8 \\
September & 13.2 & 13.8 & 11.2 & 8.3 & 23.1 & - & 21.8 & 22.7 \\
October & 4.5 & 8.3 & 4.0 & 3.7 & 14.9 & 16.6 & 14.5 & 15.3 \\
November & -6.1 & 1.7 & 1.7 & 0.5 & 4.7 & 10.7 & 10.6 & 7.3 \\
December & -4.5 & -2.4 & - & -0.4 & 1.7 & 3.5 & - & 6.4 \\
\hline
\end{tabular}

(-) No value was assigned by the Directorate of Meteorology

** $(0.0)$ There is no precipitation. Monthly maximum temperature was not given by the Directorate of Meteorology

Table 3. Some climatic data belonging to the research location

\begin{tabular}{c|c|c|c|c|c|c|c|c}
\hline \multirow{2}{*}{ Months } & \multicolumn{4}{|c|}{$\begin{array}{c}\text { Monthly total precipitation } \\
(\mathbf{m m})\end{array}$} & \multicolumn{4}{c}{$\begin{array}{c}\text { Monthly relative humidity } \\
(\boldsymbol{\%})\end{array}$} \\
\cline { 2 - 9 } & $\mathbf{2 0 1 1}$ & $\mathbf{2 0 1 2}$ & $\mathbf{2 0 1 3}$ & $\mathbf{2 0 1 4}$ & $\mathbf{2 0 1 1}$ & $\mathbf{2 0 1 2}$ & $\mathbf{2 0 1 3}$ & $\mathbf{2 0 1 4}$ \\
\hline January & 23.3 & 39.0 & 62.4 & 29.4 & 66.4 & - & - & - \\
February & 63.3 & 51.0 & 52.2 & 28.5 & - & - & - & - \\
March & 18.4 & 22.8 & 20.1 & 40.2 & 46.1 & 51.3 & 50.5 & 48.0 \\
April & 95.8 & 27.1 & 39.6 & 50.1 & 60.2 & - & 45.7 & 44.9 \\
May & 42.9 & - & 773 & 36.0 & 53.1 & - & 46.2 & 40.5 \\
June & 10.0 & 15.5 & 10.8 & 18.3 & 35.8 & 28.3 & 26.7 & 28.8 \\
July & 5.5 & 1.5 & 0.0 & 0.0 & 26.9 & 23.6 & 23.2 & 19.7 \\
August & 8.4 & 0.2 & - & 0.7 & 25.9 & 24.7 & - & 19.5 \\
September & 5.2 & 0.0 & 17.1 & 53.8 & 29.3 & - & 29.6 & 32.6 \\
October & 6.2 & 58.0 & 12.9 & 92.2 & 39.9 & - & 34.0 & 56.4 \\
November & 40.8 & 64.6 & 25.1 & 56.0 & - & - & - & - \\
December & 42.8 & 84.9 & - & 31.6 & 67.4 & - & - & - \\
\hline
\end{tabular}

*(-) No value was assigned by the Directorate of Meteorology

(0.0) There is no precipitation. Monthly maximum temperature was not given by the Directorate of Meteorology 


\section{Method}

The test was planned to be in three repetitions with 6 stocks for each one in the vineyard where the research was conducted, which was shaped like blocks.

\section{Sampling}

Sample grape clusters for each stock and each of the three repetitions were taken when the first withering started on the clusters of the stocks (Koc et al., 2015), the color and taste specific to the variety formed and the dry matter amount reached to 23-24 Brix value, and these samples were left for drying on cloth shelves.

The grapes on the dried clusters belonging to the stock in each repetition were plucked and ground in blenders. These samples were put into glass jars to be analyzed later and kept in $-20{ }^{\circ} \mathrm{C}$.

\section{Extraction of the phenolic components}

$2.5 \mathrm{~g}$ was taken from the Banazi Black grape sample which was dried, ground, and homogenized, and it was put into a falcon tube of $50 \mathrm{ml} .15 \mathrm{ml}$ of methanol:water:HCI (70:29, 9:0.1) solvent mixture which was prepared previously was added on the sample and it was homogenized. The samples which were kept in dark for $12 \mathrm{~h}$ were centrifuged at $9000 \mathrm{rpm}$ and transferred to a new supernatant falcon tube. $15 \mathrm{ml}$ solvent mixture was added on the residue and it was mixed and centrifuged again. The supernate was added to the previous one. Extraction process was repeated for the third time. After about $45 \mathrm{ml}$ of extract was obtained, the same extract was evaporated in a vacuum evaporator in inert environment until dryness. Rhe residue was dissolved with $3 \mathrm{ml}$ methanol:water (50:50), syringed, filtered through $0.45 \mu \mathrm{m}$ cellulosic filter, and the final filtrate was used in the determination of phenolic components, total phenolic substance amount and total antioxidant capacity (Milan et al., 2011).

\section{Determination of phenolic components with HPLC}

First, RT (retention time) in HPLC system and wavelength were determined for each of the 17 different phenolic standard compounds (Table 4). Then, mixture standard including all phenolic compounds was prepared and its calibration chart was drawn. Two different solvent mixtures were used as the mobile phase.

Mobile Phase A: Water: Acetic Acid (95.5\%: 4.5\%), Mobile Phase B: Acetonitrile

Table 4. Gradient program applied on HPLC system

\begin{tabular}{c|c|c|c|c}
\hline $\begin{array}{c}\text { Analysis time } \\
(\mathbf{m n})\end{array}$ & $\begin{array}{c}\text { Solvent } \\
(\mathbf{B})\end{array}$ & $\begin{array}{c}\text { Flow rate } \\
(\mathbf{m l} / \mathbf{m n})\end{array}$ & $\begin{array}{c}\text { Temperature } \\
\left({ }^{\circ} \mathbf{C}\right)\end{array}$ & $\begin{array}{c}\text { Wavelength } \\
(\boldsymbol{\lambda})\end{array}$ \\
\hline 0.01 & 0 & 1 & 30 & $280,290,355,310,329,370$ \\
7 & 5 & 1 & 30 & $280,290,355,310,329,370$ \\
12 & 15 & 1 & 30 & $280,290,355,310,329,370$ \\
20 & 40 & 1 & 30 & $280,290,355,310,329,370$ \\
25 & 100 & 1 & 30 & $280,290,355,310,329,370$ \\
30 & 100 & 1 & 30 & $280,290,355,310,329,370$ \\
40 & 5 & 1 & 30 & $280,290,355,310,329,370$ \\
\hline
\end{tabular}




\section{Determination of total phenolic substance amount}

The content of total phenolic compound was determined according to Folin-Cicalteu spectrophotometric method developed by Slinkard and Singleton (1977) in the study. "Folin \& Ciocaltue" method was used to determine total phenolic substance amount and total phenolic substance values were measured in terms of gallic acid. After $50 \mu 1$ was taken from the extracts and $950 \mu \mathrm{l}$ water was added on it, $1 \mathrm{ml}$ of Folin-Ciocaltue solution was added and it was kept waiting for $3 \mathrm{~min}$. After this period, $1 \mathrm{~mL}$ was made $3 \mathrm{~mL}$ with $2 \% \mathrm{Na}_{2} \mathrm{CO}_{3}$ solution, it was kept waiting for $10 \mathrm{~min}$, and reaction was balanced. Absorbances of the colored solutions were measured to be $760 \mathrm{~nm}$ in terms of wavelength.

\section{Determination of total antioxidant capacity}

Two tests, DPPH Radical Scavenging Power Test and TEAC (Trolox Equivalent Antioxidant Capacity) were carried out.

\section{DPPH radical scavenging power test}

Radical scavenging power (RSP) measurement was carried out according to formula 1 suggested by Yen et al. (2000). The samples which were prepared in 1.10-4 M DPPH ethanol were left for incubation at ambient temperature with extracts obtained from grape samples in $0.1 \mathrm{ml}$ of different concentrations and $2.9 \mathrm{ml}$ of DPPH solution that were put into in spectrophotometer tubs. During the control, ethanol was put instead of the sample. The absorbance of the tubes was read against $517 \mathrm{~nm}$ after $30 \mathrm{~min}$ of incubation. RSG values were calculated according to the following formula (Eq. l).

$$
\mathrm{RSG}=\left[1-\frac{\mathrm{A}_{\ddot{\mathrm{O}}: 30}}{\mathrm{~A}_{\mathrm{K}: 30}}\right] \times 100
$$

$\mathrm{A}_{\mathrm{O}: 30}$ : For example, absorbance in the $30^{\text {th }}$ min of $\mathrm{A}_{\mathrm{K}: 30}$ : Control

\section{TEAC (Trolox Equivalent Antioxidant Capacity) test}

$7 \mathrm{mM}$ ABTS (2,2-Azinobis 3-ethylbenzothiazoline 6-sulfonic acid) was mixed with $2.45 \mathrm{mM}$ potassium bisulfate and it was kept waiting in a dark environment for about 12-16 h. This solution was purified with $0.700 \pm 0.01$ absorbance in $734 \mathrm{~nm}$ wavelength with sodium acetate $(\mathrm{pH} 4.5)$ buffer in spectrophotometer, $2.98 \mathrm{~mL}$ of the solution was blended in $20 \mu \mathrm{L}$ fruit extract, and the absorbance was measured in $734 \mathrm{~nm}$ wavelength in spectrophotometer ten minutes later. The obtained absorbance values were calculated with Trolox $(10-100 \mu \mathrm{mol} / \mathrm{L})$ standard slope chart and it was stated as $\mu$ mol Trolox equivalent/g fruit (Özgen et al. 2006).

\section{Statistical analysis}

SPSS packaged software was used in determining the influence of rootstocks on photochemical characteristics and the differences between the averages were stated with Duncan multiple comparison test. 3 repetitions and the averages of 10 clusters taken from 6 vinestocks in each repetition were used for the characteristics measured in the study. Statistical materiality level was considered as $\mathrm{P}<0.05$. 


\section{Results}

\section{Findings concerning the change of phenolic components}

Quercetin, catechin, gallic acid, rutin, naringin and phloridzin dehydrate in Banazi black were found to be in identifiable levels. As can be seen in Table 5, the examined phenolic compounds were statistically significant in comparison with the rootstocks. Average gallic acid was determined to be at the lowest amount in 99R rootstock (4.10 $\mathrm{mg} / \mathrm{kg}$ ) and at the highest amount in 40-year old ungrafted vinestock $(14.43 \mathrm{mg} / \mathrm{kg})$. Catechin was at the lowest amount in $110 \mathrm{R}$ rootstock $(146.87 \mathrm{mg} / \mathrm{kg})$ and at the highest amount in 40 year-old ungrafted vinestock $(306.87 \mathrm{mg} / \mathrm{kg})$. Rutin was at the lowest amount in 99R rootstock and at the highest amount in 40-year old ungrafted vinestock (38.96-78.15 mg/kg). Naringin was determined in ungrafted young and 40 year-old vinestocks with $22.54-50.97 \mathrm{mg} / \mathrm{kg}$, Phloridzin was in $99 \mathrm{R}$ and 40 year-old ungrafted vinestocks with $40.03-107.72 \mathrm{mg} / \mathrm{kg}$, and Quercetin was in $110 \mathrm{R}$ and 40 year-old ungrafted vinestocks with $0.47-1.67 \mathrm{mg} / \mathrm{kg}$.

Table 5. Some phenolic compounds in detectable levels in the study

\begin{tabular}{c|c|c|c|c|c|c}
\hline Rootstocks & $\begin{array}{c}\text { Gallic acid } \\
\mathbf{m g} / \mathbf{k g} \text { dry }\end{array}$ & $\begin{array}{c}\text { Cateşin } \\
\mathbf{m g} / \mathbf{k g} \text { dry }\end{array}$ & $\begin{array}{c}\text { Rutin } \\
\mathbf{m g} / \mathbf{k g} \text { dry }\end{array}$ & $\begin{array}{c}\text { Naringin } \\
\mathbf{m g} / \mathbf{k g} \mathbf{d r y}\end{array}$ & $\begin{array}{c}\text { Phloridzin } \\
\mathbf{m g} / \mathbf{k g} \text { dry }\end{array}$ & $\begin{array}{c}\text { Quercetin } \\
\mathbf{m g} / \mathbf{k g} \text { dry }\end{array}$ \\
\hline Ungrafted (young) & $5.164 \mathrm{bc}$ & $212.60 \mathrm{~b}$ & $75.44 \mathrm{ab}$ & $22.54 \mathrm{~b}$ & $50.22 \mathrm{c}$ & $0.65 \mathrm{c}$ \\
Ungrafted (old) & $14.43 \mathrm{a}$ & $306.87 \mathrm{a}$ & $78.15 \mathrm{a}$ & $50.97 \mathrm{a}$ & $107.72 \mathrm{a}$ & $1.67 \mathrm{a}$ \\
$1103 \mathrm{P}$ & $8.939 \mathrm{~b}$ & $187.54 \mathrm{bc}$ & $75.48 \mathrm{ab}$ & $35.91 \mathrm{~b}$ & $79.43 \mathrm{~b}$ & $1.51 \mathrm{a}$ \\
$110 \mathrm{R}$ & $5.304 \mathrm{bc}$ & $146.87 \mathrm{c}$ & $53.75 \mathrm{c}$ & $32.68 \mathrm{~b}$ & $51.45 \mathrm{c}$ & $0.47 \mathrm{c}$ \\
$99 \mathrm{R}$ & $4.107 \mathrm{c}$ & $184.44 \mathrm{bc}$ & $38.96 \mathrm{~d}$ & $29.93 \mathrm{~b}$ & $40.03 \mathrm{~d}$ & $1.08 \mathrm{~b}$ \\
$41 \mathrm{~B}$ & $6.697 \mathrm{~b}$ & $173.23 \mathrm{bc}$ & $67.78 \mathrm{~b}$ & $34.01 \mathrm{~b}$ & $75.56 \mathrm{~b}$ & $1.04 \mathrm{~b}$ \\
Significance & 0.592 & 0.001 & 0.008 & 0.000 & 0.001 & 0.021 \\
\hline
\end{tabular}

${ }^{*} \mathrm{P}<0.05$ level of significance. Different letters show that the difference between the averages is significant according to Duncan test

Taking the average values into consideration, $99 \mathrm{R}$ and $110 \mathrm{R}$ rootstocks, known to be late season variety, were at lower levels when compared to the other rootstocks in terms of the determined phenolic compounds. The values of the clusters obtained from 40 year-old ungrafted vinestocks were recorded to be higher than the other rootstocks' values.

\section{Total antioxidant capacity $($ TAC)}

There was no statistically important difference among the rootstocks in terms of free radical (DPPH) removal activity in determining total antioxidant capacity (TAC) in the study. TAC values were determined to be $0.19-0.22 \mathrm{mg} / \mathrm{g}$ between the rootstocks (Table 6 ).

It can be seen from Table 6 that there were statistically significant between the rootstocks in determining TEAC (trolox equivalent antioxidant capacity). While the lowest average value was obtained from 99R rootstock, the highest value was determined to be in the clusters obtained from 40 year-old ungrafted vinestocks $(0.17-0.70 \mathrm{mg} / \mathrm{g})$. The values in other rootstocks were young ungrafted vinestock $0.18 \mathrm{mg} / \mathrm{g}, 1103 \mathrm{P} 0.59 \mathrm{mg} / \mathrm{g}, 110 \mathrm{R} 0.49 \mathrm{mg} / \mathrm{g}$, 41B $0.50 \mathrm{mg} / \mathrm{g}$. 
Table 6. Resveratrol, total antioxidant capacity and phenolic substance amount

\begin{tabular}{c|c|c|c|c}
\hline \multirow{2}{*}{ Rootstocks } & \multicolumn{2}{|c|}{$\begin{array}{c}\text { Total antioxidant capacity (mg trolox } \\
\text { equivalent /g antioxidant capacity) }\end{array}$} & $\begin{array}{c}\text { Total fenolik } \\
\text { (mg gallik asit/g dry) }\end{array}$ & $\begin{array}{c}\text { Resveratrol } \\
\text { (mg/kg dry) }\end{array}$ \\
\cline { 2 - 3 } & DPPH & ABTS & $11.60 \mathrm{bc}$ & $1.30 \mathrm{a}$ \\
\hline Ungrafted (young) & $0.19 \mathrm{~b}$ & $0.18 \mathrm{c}$ & $21.37 \mathrm{a}$ & $0.32 \mathrm{~b}$ \\
Ungrafted (old) & $0.20 \mathrm{ab}$ & $0.70 \mathrm{a}$ & $14.73 \mathrm{~b}$ & $0.49 \mathrm{~b}$ \\
$1103 \mathrm{P}$ & $0.21 \mathrm{a}$ & $0.59 \mathrm{ab}$ & $17.08 \mathrm{ab}$ & $0.71 \mathrm{ab}$ \\
$110 \mathrm{R}$ & $0.20 \mathrm{ab}$ & $0.49 \mathrm{~b}$ & $7.51 \mathrm{c}$ & $0.49 \mathrm{~b}$ \\
$99 \mathrm{R}$ & $0.22 \mathrm{a}$ & $0.17 \mathrm{c}$ & $21.66 \mathrm{a}$ & $0.19 \mathrm{~b}$ \\
41B & $0.19 \mathrm{~b}$ & $0.50 \mathrm{~b}$ & 0.159 & 0.021 \\
\hline Significance & 0.255 & 0.017 &
\end{tabular}

${ }^{*} \mathrm{P}<0.05$ level of significance. Different letters show that the difference between the averages is significant according to Duncan test

Bozan et al. (2008) revealed in their study, in which they investigated the antiradical effects of different grape varieties growing in our country, that different grape varieties removed DPPH radical in different proportions with the effect of their different phenolic contents.

\section{Total phenolic substance amount (TPSA)}

Average total phenolic substance amount (TPSA) in dried Banazi Black grape variety changed between 7.51-21.66 mg gallic acid/g. The differences between the rootstocks in terms of TPSA were considered statistically significant in our study. The lowest value was obtained from 99R rootstock and the highest value was obtained from 41B rootstock and 40 year-old ungrafted vinestocks (21.66-21.37 mg gallic acid/g). TPSA in the clusters obtained from the other rootstocks was $110 \mathrm{R} 17.08 \mathrm{mg} / \mathrm{g}, 1103 \mathrm{P} 14.73 \mathrm{mg}$ gallic acid/g and TPSA in ungrafted young vinestock was $11.60 \mathrm{mg}$ gallic acid/g.

Özden and Vardin (2009) determined in their study that Chardonnay $(3170 \mathrm{mg} / \mathrm{kg}$ ) variety had high phenolic substance amount, followed by $2376 \mathrm{mg} / \mathrm{kg}$ Merlot 9 variety, and total phenolic contents of Cabernet sauvignon and Syrah varieties were 1968 and $1805 \mathrm{mg} / \mathrm{kg}$, respectively.

Alphonse Lavallèe and Horoz Black grape varieties were determined to be the ones with the highest production of total phenolic substances, 3.084 and $2.832 \mathrm{mg} / \mathrm{g}$, respectively (Cetin, 2012).

In the study on ripe grapes belonging to 12 wine grape varieties, Singleton (1966) determined that total phenolic compound amount in terms of gallic acid was 3770 $\mathrm{mg} / \mathrm{kg}$ as an average value (when it is converted into the unit in our study, the result is $3.77 \mathrm{mg} / \mathrm{g}$ ). The researcher also determined that phenolic compound amounts were different according to species and varieties.

\section{Resveratrol}

It was determined as a result of the analyses that Banazi Black grape contained the phenolic compound named in many studies as resveratrol, which has antioxidant, antimutagenic, antiinflammatory, anticarcinogenetic and chemoprotective effects. 
Resveratrol amount changed in $0.19-1.30 \mathrm{mg} / \mathrm{kg}$ between the rootstocks. The lowest average value was determined in the grapes obtained from 41B rootstock and the highest value was determined in the grapes obtained from young ungrafted vinestocks. For 40 year-old ungrafted ones, it was determined to be $0.32 \mathrm{mg} / \mathrm{kg}, 1103 \mathrm{P} 0.49 \mathrm{mg} / \mathrm{kg}$, 110R $0.71 \mathrm{mg} / \mathrm{kg}$ and 99R $0.49 \mathrm{mg} / \mathrm{kg}$ (Table 6).

The flavonoid contents of $500 \mu \mathrm{l}$ fruit extract of Banazi Black are $1523.07 \mu \mathrm{g}$ catechin, $591.79 \mu \mathrm{g}$ rutin and $1.6661 \mu \mathrm{g}$ resveratrol (Özşahin, 2010).

\section{Discussion}

In this study, the changes of young-old and rootstock-variety performances in the levels of phenolic compounds, total antioxidant capacity (TAC), total phenolic substance amount (TPSA) and resveratrol after Banazi Black grape variety, which has an important position in Malatya as seed-bearing grape for drying with its gene potential, was grown on different rootstocks in its original ecology were investigated within the scope of the importance of rootstock-variety relationship in vine cultivation practices.

Because common and interconverted units are not used to evaluate phenolic compound results in literature studies, the comparison and discussion of the results have become a problem. For this reason, the obtained values were compared to the studies using similar or interconvertible units ( $\mathrm{mg} / \mathrm{kg}, \mathrm{mg} / 100 \mathrm{~g}, \mathrm{mg} / \mathrm{g}, \mathrm{g} / \mathrm{kg}$ etc.).

The differences among the rootstocks in terms of TPMS amount were considered statistically significant in our study. According to the averages, the lowest value was obtained from Banazi Black grape grafted on 99R rootstock, the highest value was obtained from Banazi Black grape grafted on 41B rootstock and 40 year-old ungrafted vinestock (21.66-21.37 mg gallic acid/g). Taking the worldwide known wine grape varieties such as Cabernet sauvignon (1968 mg/kg), Merlot (2376 mgkg), Syrah $(1805 \mathrm{mg} / \mathrm{kg})$ and edible variety Alphonse Lavallée $(3466 \mathrm{mg} / \mathrm{kg})$ into consideration (Singleton, 1966; Núñez et al., 2004; Özden and Vardin, 2009; Kelebek, 2009) 7.51$21.66 \mathrm{mg}$ gallic acid/g values (when the units were converted, Cabernet sauvignon $1.968 \mathrm{mg} / \mathrm{g}$, Merlot $2.376 \mathrm{mg} / \mathrm{g}$, Syrah $1.805 \mathrm{mg} / \mathrm{g}$, Alphonse Lavallée $3.466 \mathrm{mg} / \mathrm{g}$ ) obtained in our study were over these limits.

Aras (2006) determined that TPSA content changed between $2.88-3.42 \mathrm{mg} / \mathrm{g}$ for red grapes and 1.87-2.22 mg/g for white varieties. Karakaya et al. (2001) reported that total phenolic substance amount was $3.99 \mathrm{mg} / \mathrm{g}$ for dried grapes and $2.21 \mathrm{mg} / \mathrm{g}$ for red grapes. When these data are compared to the ones in our study, we can say that Banazi Black grape contains a very high amount of TPSA.

According to studies, while TPSA concentrations of black grapes are $1800 \mathrm{mg} / \mathrm{kg}$ on average, this value is $405 \mathrm{mg} / \mathrm{kg}$ for white varieties (Frankel et al., 1995; Shahidi and Naczk, 1995).

Cultivation conditions, rootstocks that are used, grape variety, and extraction and analytical methods that are used are considered to have an effect on the values found by the researchers.

Free radical (DPPH) removal activity was determined to be $0.19-0.22 \mathrm{mg} / \mathrm{g}$ (41B and 99R) in determining total antioxidant capacity (TAC) in the study. There was no statistically important difference among the rootstocks.

The differences among the rootstocks were considered statistically significant in determining TEAC (trolox equivalent antioxidant capacity). In terms of the averages, 
the lowest value was obtained from Banazi Black grape grafted on 99R rootstock and the highest value was in ungrafted old vinestock $(0.17-0.70 \mathrm{mg} / \mathrm{g})$.

Banazi group in the samples of $25 \mu 1$ concentrations had radical cleaning effect in a very significant proportion when compared to the other samples in a study comparing free radical cleaning activities of the grape extracts (Özsahin, 2010).

When Bozan et al. (2008) investigated the antiradical effects of different grape varieties cultivated in our country, they revealed that different grape varieties removed DPPH radical in different proportions because of their different phenolic contents.

According to a study, while CAT (catalase antioxidant enzyme) activities of Sultani seedless grape variety grafted on 1103P, 110R and 41B rootstocks in low salt concentration increased, CAT activities of Sultani seedless grape variety grafted on 1616C and 1103P rootstocks in high salt concentration increased. SOD (super oxide dismutase) activities of Sultani seedless grape variety grafted on 1103P, 110R and 99R rootstocks in high salt application increased. On the contrary, SOD activities of Sultani seedless grape variety grafted on $140 \mathrm{Ru}$ and $41 \mathrm{~B}$ rootstocks decreased. In low salt application SOD activity on $1616 \mathrm{C} 140 \mathrm{Ru}, 110 \mathrm{R}$ and $41 \mathrm{~B}$ rootstocks decreased. According to the control, AP (ascorbate peroxidase) activities of Sultani seedless grape variety grafted on 110R, 99R and 41B rootstocks in low salt application increased while AP activities of 1616C and 140Ru rootstocks decreased. AP activity of Sultani seedless grape variety grafted on 110R rootstock in high salt application increased (Sahin, 2009).

This study on Sultani seedless grape grafted on different rootstocks show that the effect of rootstocks on antioxidative enzyme activities is significant. According to our study, the statistical differences in TEAC determination on six rootstocks belonging to a single variety resulted from the rootstocks.

Quercetin, catechin, gallic acid, rutin, naringin and phloridzin dihydrate were found in detectable levels in the extracts of dried Banazi Black grape in our study. Gallic acid was determined to be at the lowest amount in Banazi Black grape grafted on 99R rootstock $(4.10 \mathrm{mg} / \mathrm{kg})$ and at the highest amount in ungrafted old vinestock (14.43 $\mathrm{mg} / \mathrm{kg}$ ). Catechin was at the lowest amount in Banazi Black grape grafted on 110R rootstock $(146.87 \mathrm{mg} / \mathrm{kg})$ and at the highest amount in ungrafted old vinestock $(306.87$ $\mathrm{mg} / \mathrm{kg}$ ). Rutin was at the lowest amount in Banazi Black grape grafted on 99R rootstock and at the highest amount in ungrafted old vinestock $(38.96-78.15 \mathrm{mg} / \mathrm{kg})$. Naringin was determined in ungrafted young and old vinestocks with $22.54-50.97 \mathrm{mg} / \mathrm{kg}$, Phloridzin was in Banazi Black grape grafted on 99R and ungrafted old vinetocks with 40.03$107.72 \mathrm{mg} / \mathrm{kg}$, and Quercetin was in Banazi Black grape grafted on 110R and ungrafted old vinestocks with $0.47-1.67 \mathrm{mg} / \mathrm{kg}$. According to a study, the amount of total phenols increase with the ripening of leaves; old leaves on the same vinestock contain more phenolic compounds than young leaves (Medeghini et al., 1992). According to our study, the phenolic compound amount obtained from ungrafted old vinestocks is higher than the phenolic compound amount obtained from Banazi Black vinestocks produced as young grafted and ungrafted vinestocks.

The differences among the detected phenolic compounds were considered statistically significant in the rootstocks. Taking these values into consideration, it is considered that the rootstocks used in our study are effective on phenolic compound amount.

In another study done by Aydınlık (2012), phenolic substance analyses of the grape molasses (pekmez) samples produced in Niğde were conducted with the method of HPLC. It was found out that grape molasses (pekmez) samples contained gallic acid, 
catechin, caffeic acid, epicatechin, p-coumaric acid and ferulic acid and their concentrations were $47.94 \pm 2.58,148.69 \pm 11.17,20.7 \pm 2.08,101.25 \pm 5.8,12.24 \pm 1.65$ and $18.26 \pm 2.58 \mathrm{mg} / \mathrm{kg}$, respectively.

Resveratrol amount changed between grafted and ungrafted rootstocks in 0.19$1.30 \mathrm{mg} / \mathrm{kg}$. the lowest value was obtained from Banazi Black grape grafted on 41B rootstock and the highest value was obtained from the young vinestock without rootstocks.

Flavonoid and resveratrol contents of Banazi Black grape extracts were determined to be $1980.00 \pm 2.88 \mathrm{mg} / \mathrm{g}$ for catechin, $769.33 \pm 2.33 \mathrm{mg} / \mathrm{g}$ for rutin, $2.16 \pm 0.16 \mathrm{mg} / \mathrm{g}$ for resveratrol (Özsahin, 2010). These values show that Banazi Black grape has a rich phenolic substance source in harmony with our study.

Bartolomeo (1996) and Zhao (1999) reported that the fundamental phenolic content of the grape consisted of resveratrol, catechin ve epicatechin. In addition, the studies showed that grape was a rich phenolic compound source and $46-69 \%$ of these phenolic compounds was in the seed, $12-50 \%$ was in the skin, $8 \%$ or less was in the pulp.

Phenolic substance amount of the grapes change depending on the variety, ripeness, environmental conditions such as climate and soil and applied cultural processes (Ribéreau-Gayon et al., 2000). However, the quality and quantity of phenolic compounds of grapes depend on grape variety. While the existence of certain phenolic substances and the proportions of their amounts to each other depend on the characteristics of species and varieties genetically controlled, total phenolic substance amount or the sort of phenols in the compound depend on environmental factors (Singleton and Esau, 1969).

The content of phenolic compounds changes based on the soil conditions in which the vinestock is cultivated and cultural applications. The soils with high sodium content and $\mathrm{pH}$ reduce phenolic substance amount in the seed, peel and stem (Quintana and Gomez, 1989), and irrigation applications increase total phenol amount in leaves and offshoots (Madero et al., 1978). Besides, the form of cultivation, rootstock and herbicide applications affect the content of phenolic substances in the vinestock and grape (Bezhanishvili et al., 1982; Smart and Smith, 1988). In line with our study, these studies conducted by other researchers show that rootstocks are effective in terms of phenolic compound contents.

In addition to the reasons reported in the previous studies, the difference in the values of our study may result from the fact that dried Banazi Black grape is ground and analyzed with its peel, pulp and seed and from the rootstocks that are used. As a matter of fact, according to a study, the $38 \%$ of the total phenol content of red and white grape varieties is seeds, $36 \%$ is peel, $20 \%$ is stem and 6\% is pulp (Flanzy et al., 1972).

The researchers who determined that pure and hybrid rootstocks used in modern vine cultivation has different effects based on the content of grape juice, wine quality and coloration (Ruhl, 1991; Bisson, 1992; Kaserer and Schofll, 1994) reported that sugars, amino acids, $\mathrm{pH}$ and $\mathrm{K}$ level in the content of anthocyanin, acidity and grape peel color changed with grafting, and acidity increased excessively with the increase in productivity and affected wine quality. 


\section{Conclusion}

One of the oldest forms of conserving fruits and vegetables is drying, its importance still continues. Drying grapes for preserving is the easiest and most economical way of conservation that has been implemented for years (Dokuzoğuz, 1972).

Because both edible grapes and various products produced from them are rich in phenolic compounds and they have bioactive characteristics for human health, grape, especially black grape, is a food product that must be a part of our nutrition.

When the data in this study is taken into consideration, the fact that grafting is effective on Banazi Black grape type produced with or without grafting, with regard to Resveratrol, Total Phenolic Substance amount, Total Antioxidant Capacity and some Phenolic Compounds, becomes more important. The obtained results are expected to provide an insight into the studies that will be conducted in future, since the current study is the first study conducted on dried grape of "Banazı".

\section{REFERENCES}

[1] Amerine, M. A., Berg, H. W., Crues, W. V. (1972): The Technology of Winemaking. AVI Publishing, Vesport, Connecticut.

[2] Anonymous (2015): Forestry and water works ministry meteorology general directorate climate datas. - Accessed 12 November 2014.

[3] Anonymous (2017): www.tuik.gov.tr/Prestatistical Table.do? istabid=65. - Accessed 25 September 2017.

[4] Aras, O. (2006): Determination of total carbohydrate, protein, mineral matter and total phenolic compound contents of grape and grape products. - Master Thesis, Süleyman Demirel University, Isparta.

[5] Aydınlık, Z. (2012): Determination of phenolic substance content of grape molasses samples produced in Niğde. - Master Thesis, Niğde University Institute of Science and Technology, Department of Chemistry.

[6] Bartolomeo, B., Hernandez, T., Bengoechea, M. L., Quesada, C., Gomez-Cordoves, C., Estrella, I. (1996): Determination of some structural features of procyanidins and related compounds by photodiode-array detection. - J Chromatogr A 723: 19-26.

[7] Bezhanishvili, K. N., Kakhiashvili, K. A., Ugrekhelidze, D. S. (1982): The effect of atrazine on the contents of some phenolic compounds of the grapevine. - VITIS Vitic Enol Abstr 21(4): 127.

[8] Bozan, B., Tosun, G., Özcan, D. (2008): Study of polyphenol content in the seeds of red grape (Vitis vinifera $L$.) varieties cultivated in Turkey and their antiradical activit. - Food Chem 109(2): 426-430.

[9] Bisson, J. (1992): Influence of rootstock on yield and quality of Sauvignon and Pinot noir grapes in Central France. - Hortic Abstr 62(12).

[10] Canbas, A. (2003): Wine technology lesson notes. - Çukurova University, Faculty of Agriculture, Adana.

[11] Canbas, A. (2006): Wine technology lesson notes. - Çukurova University, Faculty of Agriculture, Adana.

[12] Çelik, S. (1998): Viticulture (ampeloloji), Tome-1. - Trakya University, Faculty of Agriculture, Tekirdağ.

[13] Çelik, H., Ağaoğlu, Y. S., Fidan, Y., Marasalı, B., Söylemezoğlu, G. (1998): General Viticulture. - In: Sunfidan, A. Ş. (ed.) Vocational Books Series 1, 253 p. Fersa Matbaacılık San. ve Ltd. Şti., Ankara.

[14] Cemeroğlu, B. (2004): Fruit and vegetable processing technology. - Food Technology Society Publications 35(1): 77-88. 
[15] Çetin, E. S., Babalık, Z., Göktürk Baydar, N. (2012): Determination of total carbohydrate, phenolic substance, anthocyanin, $\beta$-carotene and vitamin $C$ content in some table grape varieties. - IV. National-Grape-Symposium, p. 151-159, Antalya.

[16] Doğer, E. (2004): Vineyard and wine in ancient times. - Communication Publications 25: 190.

[17] Dokuzoğuz, M. (1972): Some important problems in the drying of grapes - İTB Publication Number: 7.

[18] Fidan, Y., Yavaş, İ. (1986): The value of grapes for human nutrition. - The problems of the food industry and the effects of the free zone on the food industry. - Symposium notified, p. 225-235, Adana.

[19] Jackson, R. S. (2000): Wine Science. - Academic Press - Elsevier Science, San Diego, CA, USA.

[20] Jackson, R. S. (2003): Grapes. - In: Trugo, L. Finglas, P. M. (eds.) Encyclopedia of Food Sciences and Nutrition, p. 2957-2967. Academic Press, San Diego, CA, USA.

[21] Flanzy, M., Bourzeix, M., Heredia, N., Dobernet, M. O. (1972): The concentration and distribution of various phenolic compounds in grapes and stalks of 12 cvs. - C. R. Seances Acad Agric 58: 452-460.

[22] Frankel, E. N., Waterhouse, A. L., Tussedre, P. L. (1995): Principle phenolic phytochemicals in selected California wines and their antioxidant activity in inhibiting oxidation of human low-density Lipoprotein. - J Agric Food Chem 43: 890-894.

[23] Kafkas, E., Bozdoğan, A., Burgut, A., Türemiş, N., Paydaş, K. S., Cabaroğlu, T. (2006): Total phenol and anthocyanin contents in some grape fruits. - II. National-GrapeSymposium, p. 309-312, Tokat (in Turkish).

[24] Karakaya, S., El, S. N., Tas, A. A. (2001): Antioxidant activity of some foods containing phenolic compounds. - Intern J Food Sci Nutr 52(6): 501-508.

[25] Kaserer, H., Schofll, G. (1994): Results of a long-term experiment concerning the affinity of the cultivar Zweigelt to the rootstocks 5C, SO4, 143A, Sorisil and G9. - Amer J Enol Vitic 45(2).

[26] Kelebek, H. (2009): Researches on phenol compounds profile of Öküzgözü, Boğazkere and Kalecik Karası grapes grown in different regions and wines obtained from these grapes. - Doctoral Thesis, Çukurova University.

[27] Knekt, P., Jarvinen, R., Reunanen, A, Maatela, J. (1996): Flavonoid intake and coronary mortality in Finland: a cohort study - Br Med J 312: 478-481.

[28] Koç, H., Sağlam, H., Yağcı, A., Ernim, C., Çalkan Sağlam, Ö., Yılmaz, M., Kebeli, F. (2015): Clone selection in Banazı Black grape variety (I. Stage). - Selçuk University, Selçuk J Agric Food Sci 8 (Special Number of Symposium on Viticulture and Technology): A27, ISSN: 1309-0550.

[29] Le Marchand, L., Murphy, S .P., Hankin, J. H., Wilkens, L. R., Kolonel, L. N. (2000): Intake of flavonoids and lung cancer. - J Natl Cancer Inst 92: 154-160.

[30] Lohachoompol, V., Srzednicki, G., Craske, J. (2004): The change of total anthocyanins in blueberries and their antioxidant effect after drying and freezing. - J Biomed Biotechnol 5: 248-252.

[31] MacDougall, D. B. (2002): Colour in Food Improving Quality. - Woodhead Publishing Limited, Cambridge, England, p. 179-221.

[32] Madero, T. J., Darne, G., Bouard, J. (1978): Influence of irrigation on the composition of fatty acid and phenolic compounds in the internodes, leaves and inflorescences of vines at blossom time. - Ann Technol Agric 27: 123-125.

[33] Medeghini, B. P., Borani, F. R., Sgarbi, E. (1992): Ultrastructure, phenol content and peroxidase activity in developing leaves of Vitis vinifera, cv. Lambrusco Salamino. VITIS Vitic Enol Abstr 31(2).

[34] Milan Mitić, N., Mirjana Obradović, V., Kostić Danijela, A., Nasković Danijela, Č., Micić Ružica, J. (2011): Phenolics content and antioxidant capacity of commercial red fruit juices. Professional Paper. - Hem Ind 65(5): 611-619. 
[35] Nunez, V., Monagas, M., Gomez-Cordoves, M. C., Bartolome, B. (2004): Vitis vinifera L. cv. Graciano grapes characterized by its anthocyanin profile. - Postharvest Biol Technol 31: 69-79.

[36] Ough, C. S., Amerine, M. A. (1988): Methods for Analysis of Musts and Wines. - John Wiley and Sons, New York.

[37] Özden, M., Vardin, H. (2009): Quality and phytochemical properties of some wine grapes cultivated in Şanlıurfa conditions. - Hr. U. Z. F. Sci J 13(2): 21-27 (in Turkish).

[38] Özgen, M., Scheerens, J. C. (2006): Detection of antioxidant capacities of some red and black raspberry varieties by modified TEAC method. - National-Grape-Symposium, p. 322-332, Tokat. http://www.uzumsu.com/dosyalar/II.

[39] Özşahin, A. D. (2010): Investigation of antioxidant activities depending on phytochemical contents of some grape and apricot varieties belonging to Malatya region. - Doctorate Thesis, Firat University, Institute of Science and Technology, Elazığ.

[40] Quintana, G. M., Gomez, P. J. M. (1989): Influence of soil, climate and other factors on the phenolic content of the grape variety Xarello. - Bull O.I.V. 62: 485-497.

[41] Ribéreau-Gayon, P., Glories, Y., Maujean, A., Dubourdieea, U. (2000): Handbook of Enology. Volume 2: The Chemistry of Wine and Stabilization and Treatments. John Wiley and Sons Ltd., New York.

[42] Rolle, L., Giacosa, S., Gerbi, V., Novello, V. (2010): Comparative study of texture properties, color characteristics and chemical composition of ten white table-grape varieties. - Am J Enol Vitic 62: 49-56.

[43] Ruhl, E. H. (1991): Better rootstocks for winegrape production. - Vitis 30(4).

[44] Şahin, Ö. (2009): Determination of stress tolerance mechanisms of stressed grape varieties (Vitis vinifera l.) grafted on different suspended rootstocks with stressed antioxidant enzymes. - Master Thesis, Ankara University Institute of Natural and Applied Sciences, Department of Soil Science, Ankara.

[45] Shahidi, F., Naczk, M. (1995): Food Phenolics. - Technomic Publishing Company, Lanchester, USA, p. 199-225.

[46] Singleton, V. L. (1966): The total phenolic content of grape berries during the maturation of several varieties. - Am J Enol Vitic 17: 126-134.

[47] Singleton, V. L., Esau, P. (1969): Phenolic substances in grapes and wine and their significance. - Adv Food Res Suppl 1: 1-261.

[48] Slinkard, K., Singleton, V. L. (1977): Total Phenol Analysis: Automation and Comparation with Manual Method. - Am J Enol Vitic 28: 1-49.

[49] Smart, R. E., Smith, S. M. (1988): Canopy Management: Identifying the Problems and Practical Solutions. - In: Smart, R. E. (ed.) Proceedings of the 2nd International Symposium for Cool Climate Viticulture and Oenology. New Zealand Society for Viticulture and Oenology, Auckland, New Zealand.

[50] Yen, G. C., Chien, H. (2000): Effects of alkaline and heat treatment on antioxidative activity and total phenolics of extracts from Hsian-Tsao (Mesona Procumbens). - Hemsl Food Res Int, 33: 487-492.

[51] Zhao, J., Wang, J., Chen, Y., Agarwal, R. (1999): Anti-tumor-promoting activity of polyphenolic fraction isolated from grape seeds in the mouse skin two stage initiation promotion protocol and identification of procyanidin B5-3 gallate as the most effective antioxidant constituent. - Carcinogenesis 20: 1737-1745. 